\title{
Cytoplasmic variability in androgenetic doubled haploid lines of triticale
}

Gilles CHARMET, Fernand VEDEL $\left({ }^{*}\right)$, Michel BERNARD, Sylvie BERNARD \& Chantal MATHIEU (*)

I.N.R.A., Station d'Amélioration des Plantes, F 63039 Clermont-Ferrand

(*) C.N.R.S., Laboratoire de Photosynthèse, F 91190 Gif-sur-Yvette

The aim of this investigation is to establish if cytoplasmic alterations could be responsible for the reduction of growth vigour and low grain yield observed in certain doubled haploid lines of hexaploid triticale obtained via in vitro androgenesis.

Study of a complete $9 \times 9$ dialiel cross involving androgenetic lines and control lines on both Triticum aestivum and T. timopheevi cytoplasm showed that :

- maternal effects were non significant for 9 out of 16 quantitative characters analysed following the GRIFFING model ;

- when there were maternal effects, the androgenetic lines did not show any particular behaviour compared with the control lines, except for the green regeneration rate of androgenetic embryos.

Mitochondrial DNA analysis by electrophoresis of restriction fragments after cleavage with 6 enzymes did not show any difference between androgenetic lines and control lines on $T$. aestivum cytoplasm.

Cytoplasmic variation cannot therefore be the main explanation for the altered phenotypes observed on some androgenetic lines of hexaploid triticale.

Additional key words : $\times$ Triticosecale, doubled haploids, variants, mitochondrial DNA.

Recherche d'une variabilité cytoplasmique chez des lignées haplö̈des doublées androgénétiques de triticale.

On a recherché si d'éventuelles modifications cytoplasmiques pouvaient être responsables de la baisse de vigueur végétative et d'un faible rendement en grain de certaines lignées haploïdes doublées obtenues par androgenèse in vitro chez le triticale hexaploïde.

L'étude d'un croisement diallèle complet de taille $9 \times 9$ réalisé entre des lignées androgénétiques et des lignées témoins sur cytoplasme de Triticum aestivum ou de T. timopheevi montre que :

- Les effets maternels ne sont pas significatifs pour 9 des 16 caractères quantitatifs analysés selon le modèle de GRIFFING.

- Lorsque des effets maternels existent, on n'observe pas de comportement particulier des lignées androgénétiques par rapport aux lignées témoins, sauf pour le taux de régénération in vitro.

L'analyse des ADN mitochondriaux par électrophorèse des fragments de restriction obtenus après hydrolyse par 6 enzymes différents ne montre aucune différence entre les lignées androgénétiques et les lignées témoins sur cytoplasme de $T$, aestivum.

L'hypothèse de variations cytoplasmiques ne semble pas devoir être privilégiée pour expliquer les phénotypes inhabituels observés sur certaines lignées androgénétiques de triticale.

Mots clés additionnels : $\times$ Triticosecale, haploides doublés, variants, ADN mitochondrial.

\section{INTRODUCTION}

Many cases of « somaclonal variation " have been observed after regeneration from in vitro culture of somatic tissues, protoplasts or anthers in higher plants (LARKIN \& SCOWCROFT, 1981; SUN et al., 1983 ; LARKIN et al., 1984). Various examples of variation following in vitro androgenesis have also been described especially in tobacco (OINUMA \& YOSHIDA, 1974 ; BURK \& MATZINGER, 1976 ; DEATON et al.,
1982), rice (OONO, 1975 ; SCHAEFFER, 1982) or wheat (PICARD et al., 1978). Several hypotheses have been suggested to explain these phenomena (BROWN \& WERNSMAN, 1982) :

1) dispersion of residual heterozygosity which can remain even in advanced lines ;

2) genomic modifications during in vitro culture affecting the number and/or the structure of chromosomes ; 
3) cytoplasmic alterations which could have a direct effect or influence the regulatory systems for nuclear gene expression ;

4) modifications of the regulatory systems by derepression of genes, deletion or amplification of highly repetitive sequences of DNA.

Many authors have suggested that the cytoplasm could be responsible for certain variations found in plants regenerated through anther or somatic tissue cultured in vitro: SIBI (1976) for colour and aspect of lettuce leaves, KouAdio (1979) for biometric characters and growth dynamism in rice, SAN NOEUM \& AHMADI (1982) for precocity and vigour in barley, BROWN \& WERNSMAN (1982) for plant height in tobacco. The variants obtained in these cases do show a maternal effect when crossing on the characters considered above. More recently MATZINGER \& BURK (1984) reported changes in a cytoplasmically controlled character following anther culture in tobacco.

Hereditary modifications of cytoplasmic genetic information may have two origins : either changes in chloroplast DNA (ct DNA) or mitochondrial DNA (mt DNA) sequences by mutation, deletion, insertion or deletion of a transposable element or else a drift in mt DNA populations under the effect of a selection pressure resulting from in vitro culture conditions.

An example of cytoplasmic variation has been extensively studied in in vitro culture of maize : GENGENBACH et al., (1981) have pursued the analysis of mt DNA from plants regenerated by in vitro culture of scutellum implants of Texas male sterile maize in the presence of toxine from Drechslera maydis race $\mathrm{T}$ (specific to the Texas cytoplasm). Most of the plants were both resistant and male fertile, and showed restriction fragment patterns of mt DNA different from those of the classic cytoplasms $\mathrm{N}$ and $\mathrm{T}$. Similar results were found in fertile and sterile maize plants derived from tissue culture of maize ( $T$ cytoplasm) without $T$ toxin (KEMBLE et al., 1982). Specific mitochondrial gene products are also modified (DIXON et al., 1982). In another case, CHOUREY \& KEMBLE (1982) have described a specific type of mt DNA variation which is correlated with friable callus morphology in maize cultured in vitro : this variation was restricted to the plasmid like DNA species $\mathrm{S} 1$ and $\mathrm{S} 2$ and presumably arose from transpositional events. These observations confirm that cytoplas- mic modification may occur during in vitro culture, with or without a specific selection pressure.

It has been shown that the mt DNA of higher plants is often organized into several discrete size classes of linear or circular molecules (QUETIER \& VEDEL, 1977; LEVINGS et al., 1979). It can be suggested that these heterogeneous populations of mt DNA molecules are subject to drift during in vitro culture. Moreover, it has recently been proved that different circular forms of mt DNA molecules can recombine together across a common repeat element (LONSDALE et al., 1983 ; FALCONNET et al., 1984 ; PALMER \& ShIELDS, 1984). The last authors have put forwards the hypothesis that cytoplasmic modifications during in vitro culture may result from secondary recombination processes which normally occur at very low frequency in native plant tissues but which are intensified when plant cells are cultured in vitro.

The aim of this study is to investigate possible cytoplasmic alterations in five androgenetic lines of hexaploid triticale ( $\times$ Triticosecale Wittmack) previously obtained (BERNARD, 1977, 1980) by biometrical analysis on a diallel cross and electrophoresis of mt DNA restriction fragments.

\section{MATERIAL AND METHODS}

\section{A. Genetic analysis}

A complete diallel cross was made using the following lines of hexaploid triticale (their main agronomic characteristics are summarized in table 1).

- 5 doubled haploid lines, AN1 to AN5, obtained by in vitro androgenesis from $4 \mathrm{~F} 1$ hybrids between hexaploid triticale lines of diversified origins (AN1 and AN3 are sister lines issued from the same F1 plant). AN1, AN2 and AN3 have unexpected phenotypes in relation to the original material : they are fairly short, with poor growth vigour, reduced fertility, shrivelled kernels and therefore a low grain yield. AN4 and AN5, however, show phenotypes which correspond to those of their parents and have a satisfactory grain yield ;

TABLE 1

Main agronomic characteristics of the 9 parental lines used in the diallel cross (trial 1982-83).

Principales caractéristiques agronomiques des 9 parents du croisement diallèle (essai 1982-83).

\begin{tabular}{lcccccccc}
\hline \multicolumn{1}{c}{ Line } & Code & $\begin{array}{c}\text { Cytoplasm } \\
\text { Donor }\end{array}$ & $\begin{array}{c}\text { Height } \\
\mathrm{cm}\end{array}$ & $\begin{array}{c}\text { Heading } \\
\text { date in May }\end{array}$ & $\begin{array}{c}\text { Grain yield } \\
\text { 1/ha }\end{array}$ & $\begin{array}{c}\text { 1 000 grain } \\
\text { weight g }\end{array}$ & $\begin{array}{c}\text { Test weight } \\
\mathrm{kg} / \mathrm{hl}\end{array}$ & $\begin{array}{c}\text { Protein content } \\
\% \text { D.M. }\end{array}$ \\
\hline A 89-30 & AN1 & F1 A89 & 105 & 28 & 4.12 & 37.5 & 62.9 & 15.14 \\
A 114-3 & AN2 & F1 A114 & 100 & 30 & 3.16 & 29.5 & 57.9 & 16.19 \\
A 89-36 & AN3 & F1 A89 & 95 & 25 & 3.21 & 36.5 & 53.5 & 17.35 \\
A 62-1 & AN4 & F1 A62 & 110 & 21 & 6.22 & 50.0 & 67.8 & 11.30 \\
A 78-1 & AN5 & F1 A72 & 120 & 29 & 5.71 & 46.0 & 66.7 & 14.99 \\
86 042-1 & GE6 & T. aestivum & 115 & 30 & 2.25 & 48.0 & 65.8 & 19.22 \\
532 D 28 & GE7 & T. aestivum & 125 & 26 & 6.55 & 39.0 & 61.9 & 13.10 \\
T 764 & GE8 & T. timopheevi & 145 & 28 & 2.24 & 42.0 & 61.6 & 15.89 \\
Triton & GE9 & T. aestivum & 90 & 14 & 5.87 & 41.5 & 63.3 & 14.80 \\
Clercal & (Control) & T. aestivum & 125 & 25 & 6.18 & 46.0 & 73.1 & 13.45 \\
\hline \hline
\end{tabular}


- 4 lines, GE6 to GE9, produced by 'classical' pedigree selection. GE6 is an F7 line from a cross between a Danish octoploid and a hexaploid triticale ; in spite of good growth vigour, this line is low yielding. GE7 is an F6 line from a triticale $\times$ bread wheat cross, of good agricultural value. GE8 is an isogenic line of an American variety (Fas Gro) transfered to the cytoplasm of Triticum timopheevi by Y. CAUdERON. This line which has a cytoplasm very different from that of the other lines (Triticum aesti$v u m$ ) can thus be used as a control. GE9 is a commercial line, 'Triton', with a Mexican genetic background. It is short, early, spring type and cold sensitive.

All the F1's and parents of the diallel were put on trial in 1982-83, following a factorial design so that each of the two locations contained two randomised replications :

- Clermont-Ferrand : $\mathbf{3 3 0} \mathrm{m}$ in altitude, isohumic deep clay soil, a semi-continental climate with low rainfall (600 mm/year). Sown 12 November 1982 ;

- Bourg-Lastic : $60 \mathrm{~km}$ to the west of ClermontFerrand, altitude $860 \mathrm{~m}$, acid brown sandy soil with low water retention, mountain climate fairly rainy $1200 \mathrm{~mm} /$ year) with frequent snow. Sown $30 \mathrm{Sep}-$ tember.

Each plot consisted of three 1 meter long, $0.2 \mathrm{~m}$ spaced rows with 8 seeds per row (sowing density of 40 grains $/ \mathrm{m}^{2}$ ), and a space of $\cdot 0.4 \mathrm{~m}$ between the plots. Fourteen quantitative characters were measured in the field or after harvest (August 1983), mostly for the two places (CF-BL) but some only at ClermontFerrand (CF), others only at Bourg-Lastic (BL) :

(1) Winter hardiness (BL) : in $\%$ of plants winter surviving.

(2) Heading date $(\mathrm{CF})$ : number of days after that of 'Triton', the earliest variety.

(3) Susceptibility to brown rust (Puccinia recondita) (CF-BL) : visual score from $1=$ no attack, to 9 .

(4) Susceptibility to glume blotch (Septoria nodorum) on leaves (CF-BL) : score 1-9.

(5) Susceptibility to glume blotch on ears: \% of spikelets infected.

(6) Plant height in $\mathrm{cm}$ (CF-BL) measured in the plot.

(7) Number of spikelets per main ear (CF-BL) : 10 counts per plot.

(8) Flag leaf area in $\mathrm{cm}^{2}$ (CF) calculated by $\mathrm{S}=0.79 \mathrm{~L} \times \mathrm{I}$ where $\mathrm{L}$ and $\mathrm{I}$ are the length and maximum width respectively, according to SIMPSON (1968) : 5 measurements per plot.

(9) Tillering (CF-BL) : number of fertile tillers per plot.

(10) Grain yield (CF-BL) : in $g$ of dry grain per plot.

(11) 1000 grain weight (CF-BL) in g, measured on 250 grains.

(12) Mean grain number per ear (CF-BL) : $(12)=(10) /(11) \times(9)$.

(13) Test weight (CF-BL) in $\mathrm{kg} / \mathrm{hl}$, measured on $100 \mathrm{ml}$ of grain.

(14) Protein content $(\mathrm{CF})=$ content of $\mathrm{N}$ (Kjeldahl) $\times 6.25$.

We have also added the results from the study of two characters concerning in vitro androgenesis responsiveness carried out on a sub-diallel $7 \times 7$ of the previous diallel cross (parents: AN1, AN2, AN3, AN5, GE6, GE7 and GE8) during spring 1983: the experimental design consisted of 3 greenhouse replications and two culture media, one solidified with agar, the other liquid (CHARMET \& BERNARD, 1984) :

(15) Embryogenesis : number of embryos per 100 anthers cultivated.

(16) Regeneration: number of green plantlets per 100 embryos transferred to the regeneration medium.

The original data for characters $1,5,15$ and 16 were transformed by the Arcsin $\sqrt{\mathrm{x}}$ function in order to normalize the distributions. The set of data was then treated with GRIFFING's Model 1 (fixed effects) Method 1 (complete diallel) analysis (GRIFFING, 1956).

The computer programme consists of an analysis of variance on the factorial trial (or 'block' trial for some characters) followed by the breakdown of the genotypic variance into variances related to :

- General Combining Ability (GCA).

- Specific Combining Ability (SCA).

- Reciprocal effects.

with a FISHER $F$ test of their significance.

The effects linked to the parents (GCA and general reciprocal effects or 'maternal' effects) and to the combinations (SCA and specific reciprocal effects) were then calculated from the original data and tested for their significance.

\section{B. Analysis of mitochondrial DNA (mt DNA)}

The isolation of mitochondria (from about $100 \mathrm{~g}$ of fresh etiolated seedlings), the extraction and purification of $\mathrm{mt}$ DNA, their hydrolysis by restriction endonucleases, then the electrophoresis on agarose gels of the fragments obtained were carried out following the protocol already described by VEDEL \& QUETIER (1978). The gels were photographed under U.V. light after ethidium bromide staining.

The analysis concerned 5 androgenetic lines: AN1 to AN5 as well as line GE6 (of poor agricultural value) and the bread cv 'Capitole'. We have not repeated the analysis of the mt DNA of $T$. timopheevi, already known to have restriction diagrams very different from those of $T$. aestivum (VEDEL et al., 1981).

The 6 following restriction endonucleases were used : Eco RI, Bgl I, Sal I, Kpn I, Pst I and Sma I. The fragments resulting from the digestion of $\lambda$ phage DNA by Eco RI have been added as molecular weight markers. The extraction for the line AN4 was not good, so the diagrams for Eco RI and Bgl I were not carried out and are only faintly discernible for the other enzymes. Only AN2, AN3, AN5 and 'Capitole' were analyzed with Sma I.

\section{RESULTS}

\section{A. Biometrical study}

Table 2 presents the results of the variance analysis carried out on the factorial design or on a block trial. 
TABLE 2

Analysis of variance (mean squares) on factorial design or block design.

Analyse de variance (carrés moyens) sur essai factoriel ou essai bloc.

\begin{tabular}{|c|c|c|c|c|c|c|}
\hline $\begin{array}{l}\text { Source of } \\
\text { variation } \\
\text { Character }\end{array}$ & Replication & Medium & Genotype & $\underset{\text { Interaction }}{\mathrm{G} \times \mathrm{M}}$ & Error & $\begin{array}{l}\text { Coef. of } \\
\text { variation }\end{array}$ \\
\hline 1 & 1.00 & - & $231.1^{* *}$ & - & 112.4 & 12.7 \\
\hline 2 & 1.35 & - & $35.5^{* *}$ & - & 1.06 & 10.1 \\
\hline 3 & 0.01 & $12.6^{* *}$ & $10.0^{* *}$ & $0.96^{* *}$ & 0.37 & 26.8 \\
\hline 4 & $5.18^{* *}$ & $10.0^{* *}$ & $4.4^{* *}$ & $2.24^{* *}$ & 0.50 & 21.9 \\
\hline 5 & $91.7 * *$ & $763.3^{* *}$ & $55.1^{* *}$ & $31.1 * *$ & 16.4 & 24.8 \\
\hline 6 & 3.00 & $9440.0^{* *}$ & $744.8^{* *}$ & $64.2 * *$ & 18.3 & 3.6 \\
\hline 7 & 0.01 & $384.5^{* *}$ & $49.8^{* *}$ & $2.9 * *$ & 1.54 & 3.8 \\
\hline 8 & $46.4 * *$ & - & $79.4^{* *}$ & - & 28.4 & 11.1 \\
\hline 9 & $966.0 * *$ & $2 \times 10^{6 * *}$ & $2162.3^{* *}$ & $1240.7^{* *}$ & 557.8 & 14.9 \\
\hline 10 & 1760.0 & $2.5 \times 10^{6 * *}$ & $32286 * *$ & $17277 \quad * *$ & 6133 & 24.7 \\
\hline 11 & $53.3^{* *}$ & $349.6^{* *}$ & $148.6^{* *}$ & $20.7^{* *}$ & 12.2 & 7.3 \\
\hline 12 & 4.4 & $38922 * *$ & $516.6^{* *}$ & $146.5 * *$ & 49.5 & 15.0 \\
\hline 13 & $27.0 * *$ & $2551 \quad * *$ & $17.9^{* *}$ & $12.3 * *$ & 3.55 & 2.8 \\
\hline 14 & 77.9 & - & $633.3^{* *}$ & - & 124.0 & 19.2 \\
\hline 15 & $212.9 * *$ & $5372 * *$ & $581.1^{* *}$ & $111.1 * *$ & 8.5 & 17.4 \\
\hline 16 & $95.8 * *$ & - & $143.3^{* *}$ & - & 14.5 & 30.2 \\
\hline
\end{tabular}

Genotypic effects were always significant, although for some characters the coefficients of variation indicate a fairly bad precision of the trials.

Table 3 shows the breakdown of the genotypic variance, according to GRIFFING's model, into variance related to the GCA, variance related to the SCA and variance related to Reciprocal Effects (R.E.). Their significance was tested in relation to the residual variance.

Account has also been taken of the GCA/SCA mean squares ratio, a high value of which indicates a preponderance of additive effects in the genetic control of the character considered.

We were particularly interested by the part of the genotype variance which could be explained by reci- procal effects, i.e. general reciprocal effects or maternal effects (MAT) and specific reciprocal effects.

In 9 out of 16 cases, reciprocal effects were not significant. It could therefore be concluded that there was no cytoplasmic influence on the genetic control of character $\mathrm{n}^{\text {os }} 2,3,4,5,7,8,11,13$ and 14 . For the 7 characters exhibiting significant reciprocal effects, table 4 shows the values of the GCA and the General Reciprocal effect or 'maternal effect' (MAT) of each of the 9 parents ( 7 for the traits concerning in vitro androgenesis). The maternal effect values were often greatly inferior to the GCA values, which represent the part of additive gene action in determining the character considered. Examining character by character the MAT values and their distribution

TABLE 3

Breakdown of genetic variance according to GRIFFING's model.

Décomposition de la variance génotypique selon le modèle de GRIFFING.

\begin{tabular}{|c|c|c|c|c|c|}
\hline $\begin{array}{l}\text { Source of } \\
\text { variation } \\
\text { Character }\end{array}$ & GCA & SCA & $\mathrm{GCA} / \mathrm{SCA}$ & $\begin{array}{c}\text { Reciprocal } \\
\text { effects }\end{array}$ & Error \\
\hline 1 & $197.7^{* *}$ & $131.3 * *$ & 1.5 & $105.0^{*}$ & 64.3 \\
\hline 2 & $161.7^{* *}$ & $2.7 * *$ & 59.0 & $0.7 \mathrm{NS}$ & 0.5 \\
\hline 3 & $16.9^{* *}$ & $1.7 * *$ & 10.1 & $0.1 \mathrm{NS}$ & 0.1 \\
\hline 4 & $6.5^{* *}$ & $0.9^{* *}$ & 7.3 & $0.1 \mathrm{NS}$ & 0.1 \\
\hline 5 & $44.8^{* *}$ & $16.6^{* *}$ & 2.7 & $4.1 \mathrm{NS}$ & 4.1 \\
\hline 6 & $1454.4^{* *}$ & $81.8^{* *}$ & 17.8 & $8.6^{*}$ & 4.6 \\
\hline 7 & $105.6^{* *}$ & $3.6^{* *}$ & 28.9 & $0.5 \mathrm{NS}$ & 0.4 \\
\hline 8 & $156.9^{* *}$ & $31.2^{* *}$ & 5.0 & 16.2 NS & 14.2 \\
\hline 9 & $1923.9^{* *}$ & $439.5^{* *}$ & 4.4 & $334.2^{* *}$ & 139.4 \\
\hline 10 & $40983 * *$ & $9645.2^{* *}$ & 4.2 & $3073.2^{* *}$ & 1533.9 \\
\hline 11 & $134.1^{* *}$ & $48.7^{* *}$ & 2.7 & $3.9 \mathrm{NS}$ & 3.0 \\
\hline 12 & $820.0^{* *}$ & $84.5^{* *}$ & 9.7 & $20.2^{*}$ & 12.4 \\
\hline 13 & $33.5^{* *}$ & $1.5 * *$ & 22.0 & $0.9 \mathrm{NS}$ & 0.9 \\
\hline 14 & $1072.8^{* *}$ & $369.0^{* *}$ & 2.9 & $96.3 \mathrm{NS}$ & 62.5 \\
\hline 15 & $355.4^{* *}$ & $68.6^{* *}$ & 5.2 & $51.3^{* *}$ & 1.4 \\
\hline 16 & $205.7^{* *}$ & $70.0^{* *}$ & 2.9 & $34.9^{* *}$ & 7.2 \\
\hline
\end{tabular}

$*,\left({ }^{* *}\right)$ : Significant effect at the $5 \%(1 \%)$ level of probability. 
among androgenetic lines and pedigree lines, it can be seen that :

- for winter hardiness, line GE7 only, obtained by pedigree selection, showed a significant, positive maternal effect ;

- for plant height, two androgenetic lines showed significant maternal effects. AN5 had a positive effect and AN3 a negative one, but their values were low compared to the GCA value of AN3 ;

- for fertile tillering and grain yield (these two variables are positively correlated), two doubled haploid lines, AN1 and AN5 showed a positive maternal effect, whereas lines GE6 (on $T$. aestivum cytoplasm) and GE8 (on $T$. timopheevi cytoplasm) had a negative maternal effect, as did also GE9 on tillering ;

- for ear fertility, only line AN5 had a significant, negative maternal effect, which was related to the positive maternal effect on tillering;

- for in vitro embryogenesis, only GE8, on $T$. timopheevi cytoplasm showed a significant, positive maternal effect ;
- for green plant regeneration, AN1 had a negative maternal effect and AN3 a positive, highly significant one.

Table 5 recapitulates, for each character, the number of combinations involving each parent that showed significant specific reciprocal differences. The distribution of these specific reciprocal effects seemed random, except for the combinations involving GE8 as female parent that were superior to their reciprocal on in vitro embryogenesis. The 5 androgenetic lines did not present a particular behaviour which could be attributed to nucleocytoplasmic interactions : none of them were involved more frequently than pedigree lines in combinations showing reciprocal effect, nor did they systematically present positive or negative signs.

\section{B. Analysis of mitochondrial DNA}

The electrophoretic diagrams on agarose gels of $\mathrm{mt}$ DNA restriction fragments obtained with the Sal I, Kpn I, Pst I, Eco RI, Bgl I and Sma I enzymes from

TABLE 4

Maternal effects and GCA values of each parent for 7 characters showing significant reciprocal effects.

Valeur des effets maternels et de l'AGC de chaque parent pour les 7 caractères présentant des effets de réciprocité générale.

\begin{tabular}{|c|c|c|c|c|c|c|c|c|}
\hline \multirow{2}{*}{\multicolumn{2}{|c|}{$\begin{array}{c}\text { Character } \\
\text { Parent }\end{array}$}} & \multirow{2}{*}{$\begin{array}{c}\text { (1) } \\
\text { Winter } \\
\text { Hardiness }\end{array}$} & \multirow{2}{*}{$\begin{array}{c}\text { (6) } \\
\text { Height }\end{array}$} & \multirow{2}{*}{$\begin{array}{c}\text { (9) } \\
\text { Tillering }\end{array}$} & \multirow{2}{*}{$\begin{array}{c}10 \\
\text { Grain } \\
\text { yield }\end{array}$} & \multirow{2}{*}{$\begin{array}{l}12 \\
\text { grains/spike }\end{array}$} & \multirow{2}{*}{$\begin{array}{l}15 \\
\text { Embryogenesis }\end{array}$} & \multirow{2}{*}{$\begin{array}{c}16 \\
\text { Regeneration }\end{array}$} \\
\hline & & & & & & & & \\
\hline \multirow{2}{*}{ AN1 } & $\mathrm{GCA}$ & 2.82 & $1.82^{*}$ & $11.01 * *$ & 20.08 & 0.49 & $-2.06^{* *}$ & $0.99^{*}$ \\
\hline & $M A T$ & -0.61 & -0.03 & $6.54^{*}$ & $27.53^{* *}$ & 1.37 & 0.76 & $-1.71^{*}$ \\
\hline \multirow{2}{*}{ AN2 } & GCA & 2.15 & $-8.89^{* *}$ & -2.53 & $-24.10^{* *}$ & $2.44^{*}$ & $-4.82^{* *}$ & $3.24^{* *}$ \\
\hline & $M A T$ & 2.00 & 0.42 & 0.89 & 2.58 & 0.17 & -1.00 & -0.58 \\
\hline \multirow{2}{*}{ AN3 } & GCA & 0.79 & $-11.96^{* *}$ & $5.43^{*}$ & 9.27 & $3.15^{*}$ & -0.37 & $3.05^{* *}$ \\
\hline & $M A T$ & 1.69 & $-1.87^{*}$ & -2.45 & -5.28 & 1.06 & -1.23 & $2.87^{* *}$ \\
\hline \multirow{2}{*}{ AN4 } & GCA & -1.98 & -0.60 & $-6.31^{*}$ & $62.23 * *$ & $9.02^{* *}$ & & \\
\hline & $M A T$ & $-2.8 I$ & 0.46 & -2.03 & 6.96 & 0.57 & & \\
\hline \multirow{2}{*}{ AN5 } & GCA & 0.82 & -0.81 & $19.43^{* *}$ & $51.32^{* *}$ & 1.61 & $-6.82^{* *}$ & $-1.80^{* *}$ \\
\hline & $M A T$ & -1.44 & $1.69 *$ & $16.37^{* *}$ & $23.18^{* *}$ & $-2.09^{*}$ & -1.03 & -0.25 \\
\hline \multirow{2}{*}{ GE6 } & GCA & $6.76^{* *}$ & $4.69^{* *}$ & -0.11 & 4.09 & -0.57 & $10.73 * *$ & $-3.71 * *$ \\
\hline & $M A T$ & -0.33 & -0.42 & $-10.39 * *$ & $-22.58^{* *}$ & -0.03 & -3.91 & -0.21 \\
\hline \multirow[b]{2}{*}{ GE7 } & GCA & $-4.96^{* *}$ & $3.49^{* *}$ & -4.57 & 15.71 & $5.06^{* *}$ & $-1.31^{*}$ & $-3.24 * *$ \\
\hline & $M A T$ & $4.17^{*}$ & 0.72 & 4.93 & -0.34 & -0.63 & -0.58 & -1.23 \\
\hline \multirow{2}{*}{ GE8 } & GCA & -1.07 & $18.59 * *$ & $-13.39^{* *}$ & $-88.85^{* *}$ & $-13.2^{* *}$ & $4.65^{* *}$ & $1.47^{* *}$ \\
\hline & $M A T$ & -0.89 & -0.62 & $-7.11^{*}$ & $-18.50^{*}$ & -0.83 & $7.00^{* *}$ & 1.11 \\
\hline \multirow{2}{*}{ GE9 } & GCA & $-5.35^{* *}$ & $-6.33^{* *}$ & $-8.97^{* *}$ & $-49.73^{* *}$ & $-7.98^{* *}$ & & \\
\hline & $M A T$ & -1.78 & -0.35 & $-6.75^{* *}$ & 0.37 & 0.41 & & \\
\hline
\end{tabular}


TABLE 5

Number of implications of each parent in combinations showing specific reciprocal differences and their signs. Nombre d'implications de chaque parent dans des combinaisons présentant des écarts de réciprocité spécifiques pour 7 caractères et leurs signes.

\begin{tabular}{|c|c|c|c|c|c|c|c|}
\hline Character & (1) & (6) & (9) & (10) & (12) & $(15)$ & (16) \\
\hline Line & Winter hardiness & Plant height & Fertile tillering & grain yield & grains/spike & $\begin{array}{c}\text { in vitro } \\
\text { embryogenesis }\end{array}$ & $\begin{array}{l}\text { in vitro } \\
\text { regeneration }\end{array}$ \\
\hline AN 1 & $1(+)$ & 0 & $1(+)$ & $1(+)$ & $2(++)$ & $1(+)$ & $3(--+)$ \\
\hline AN2 & $1(+)$ & $2(++)$ & $2(-+)$ & 0 & $1(-)$ & $1(-)$ & $2(+-)$ \\
\hline AN3 & $2(-+)$ & $1(-)$ & $1(-)$ & $2(-+)$ & 0 & $3(++-)$ & $2(++)$ \\
\hline AN4 & $2(--)$ & $2(t+)$ & $1(-)$ & $2(-+)$ & 0 & - & - \\
\hline AN5 & $1(-)$ & $2(++)$ & $2(++)$ & $2(+-)$ & $2(--)$ & $1(-)$ & 0 \\
\hline GE6 & 0 & $2(--)$ & $1(-)$ & $2(-+)$ & $1(+)$ & $2(--)$ & 0 \\
\hline GE7 & $2(t+)$ & 0 & $1(-)$ & 0 & $2(+-)$ & 0 & $2(--)$ \\
\hline GE8 & $2(--)$ & $2(--)$ & $2(--)$ & 0 & 0 & $4(++++)$ & $1(+)$ \\
\hline GE9 & $1(+)$ & $1(-)$ & $1(-)$ & $2(-+)$ & $1(+)$ & - & - \\
\hline
\end{tabular}

the 5 androgenetic lines and two controls (GE6 and the bread wheat 'Capitole') are presented in figures 1 and 2.
The 5 androgenetic doubled haploid lines showed restriction patterns exactly the same as those of the controls for each of the 6 endonucleases tested. The

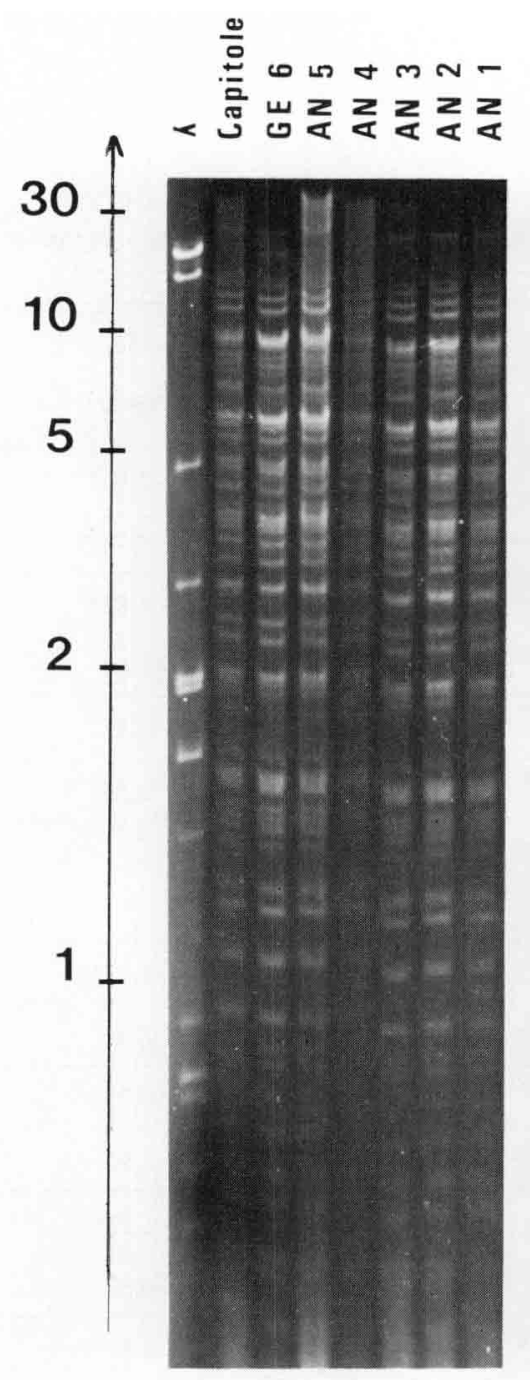

\section{$M W \times 10^{6} \quad K P N \quad$}
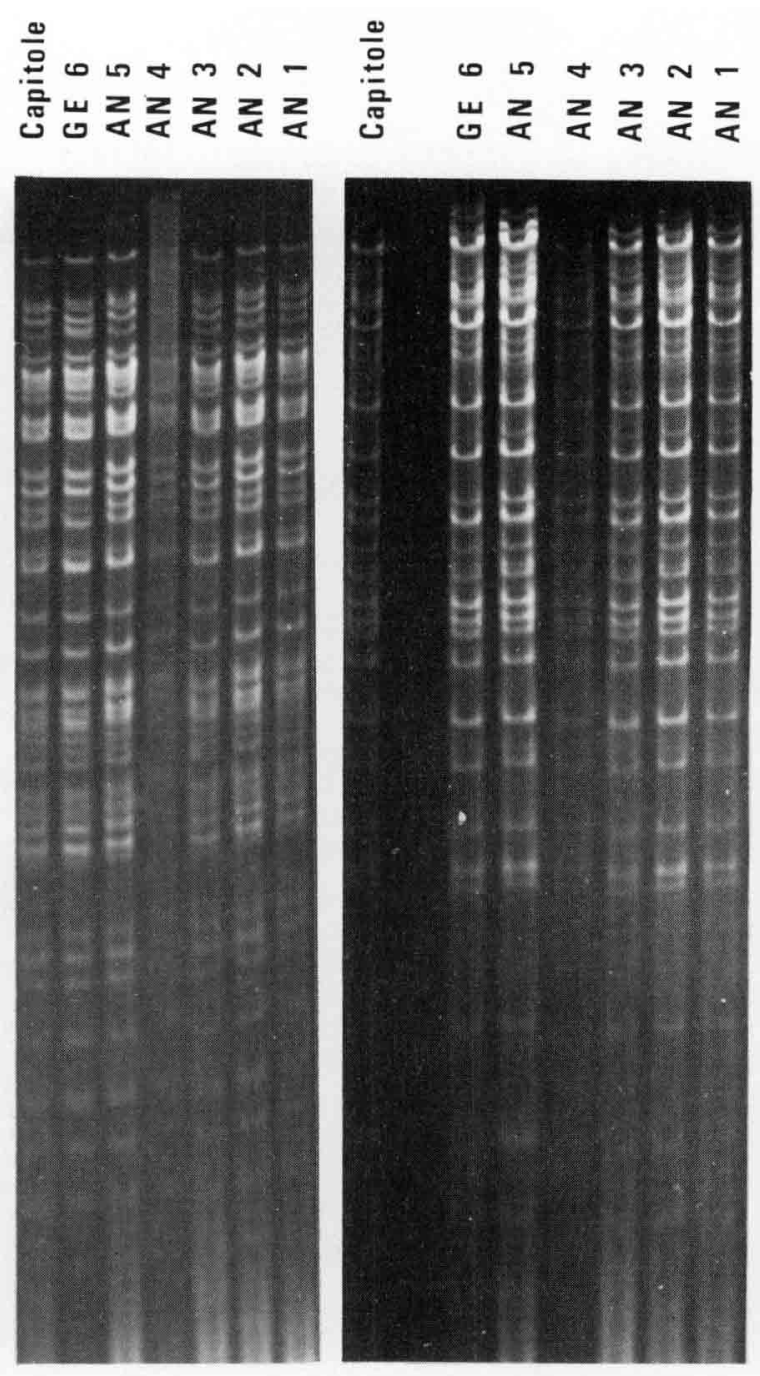

SAL I

PST I
Figure 1

Electrophoregrams of restriction fragments obtained after cleavage with the KPN I, PST I and SAL I enzymes of $m$ DNAs from $A N 1, A N 2, A N 3, A N 4, A N 5, A N 6$, GE6 and 'Capilole'.
Electrophorégrammes des fragments de restrictions obtenus après hydrolyse par les enzymes KPN I, PST I et SAL I, des mt DNA de $A N 1, A N 2, A N 3, A N 4, A N 5$, GE6 et « Capitole». 


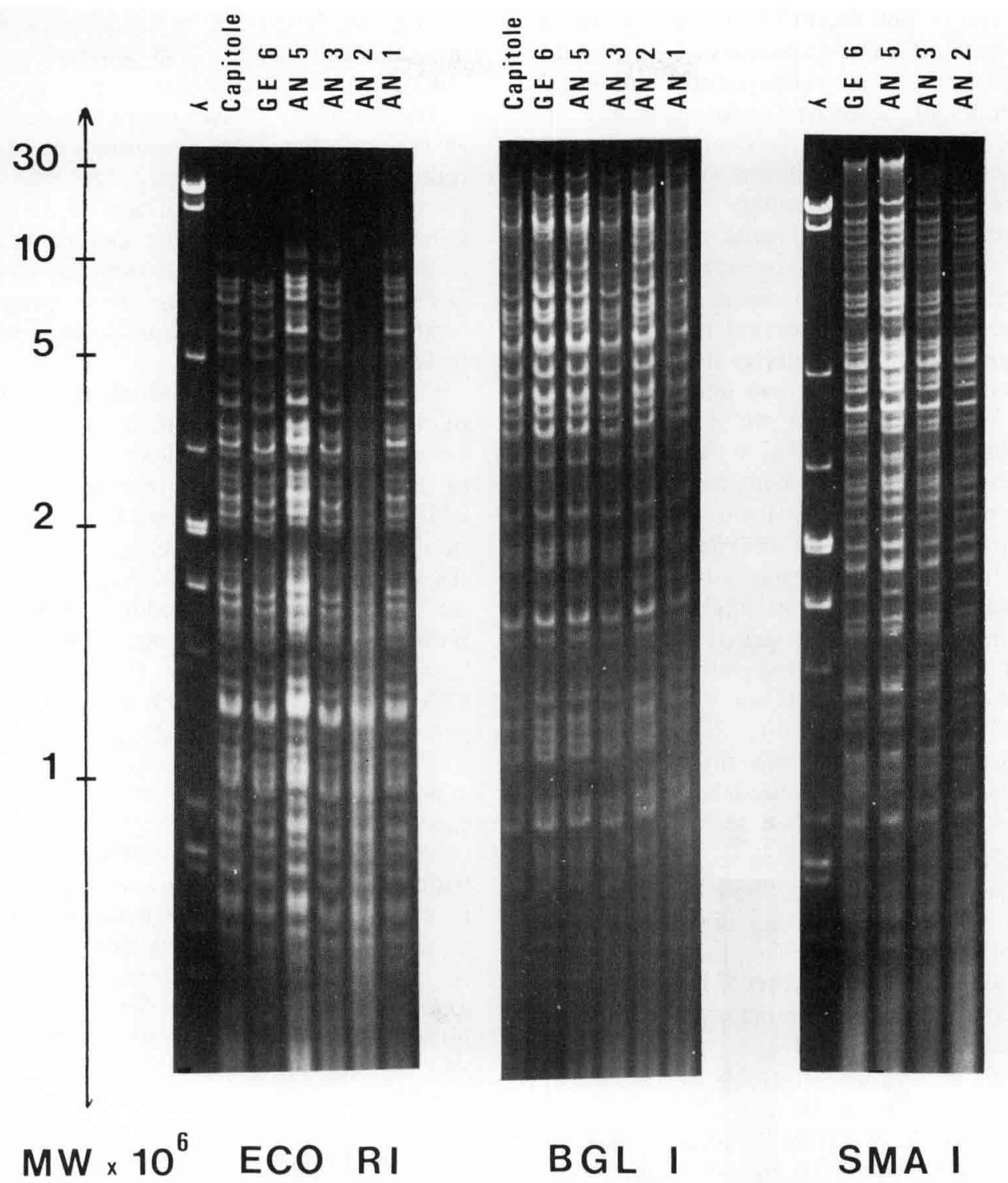

Figure 2

Electrophoregrams of restriction fragments obtained after cleavage with the ECO RI, BGL I and SMA I enzymes of mi DNAs from $A N I, A N 2, A N 3, A N 5$, GE6 and 'Capitole'.

same bands were present on each diagram and, moreover, there was no evidence for change in the stoichiometry of any restriction fragment.

\section{DISCUSSION AND CONCLUSION}

Cytoplasmic modifications in androgenetic lines of triticale were investigated through diallel analysis because cytoplasmic effects could lead to differences between reciprocal hybrids for quantitative characters. The alien cytoplasm of $T$. timopheevi has a general reciprocal effect on two groups of characters :

- fertile tillering and grain yield, for which the effect of alien cytoplasm is negative. It is to be noted that another line, GE6, on $T$. aestivum cytoplasm, also shows a significant maternal effect ;

- in vitro embryogenesis, with a positive effect, already observed by PICARD et al. (1978) in alloplasmic lines of bread wheat.

Electrophorégrammes des fragments de restriction obtenus après hydrolyse par les enzymes ECO RI, BGL I et SMA I, des mt DNA des $A N 1, A N 2, A N 3, A N 5$, GE6 et «Capitole ».

For these same characters, the maternal effects of the androgenetic lines are either non-significant (embryogenesis) or positive, as in the case of AN1 and AN5 for tillering and grain yield. The improved androgenetic behaviour observed for the same androgenetic lines created during a previous cycle of anther culture (PICARD et al., 1978) was not found in our study. It is also difficult to explain the deficiency of androgenetic lines AN1, AN2 and AN3 by cytoplasmic alterations, since on the contrary, the general reciprocity effects (maternal effects) shown, when significant, were positive. The maternal effects found on plant height for AN3 and AN5 were low compared to the GCA values and only significant at the $5 \%$ level.

It has been verified that possible cytoplasmic variation affecting androgenetic lines could be expressed as a specific interaction with a given nuclear genotype, leading to the appearance of a specific reciprocal effect. It is thus clear that the cytoplasm of 
androgenetic lines is not modified uniformly by in vitro anther culture. If some variations exist, they do not confer to these lines unfavourable maternal effects on vigour or improved responsiveness to anther culture. The "variant" characters (short height, shrivelled grains and reduced yield) observed in some androgenetic lines cannot therefore be attributed in our study to cytoplasmic variations.

A particular mention must be made of green plantlet regeneration from androgenetic embryos : the AN3 line showed a positive maternal effect, significant at $1 \%$, and AN1 had a negative maternal effect significant at the $5 \%$ level. If these maternal effects are to be effectively ascribed to a cytoplasmic influence, it should be concluded that AN1 and AN3 show differences in the genetic constitution of their cytoplasm. Since they originate from the same F1 plant, this implies an effect of in vitro culture on cytoplasm : the possible cytoplasmic alteration could involve the mitochondria or more likely the chloroplasts. Indeed most of the androgenetic plantlets of triticale are albinos, and the green/albino plantlets ratio explains most of the variation between genotypes in level of green regeneration.

Studies on rice have shown that the albinism of androgenetic plants could be caused by chloroplast DNA alterations (SUN et al., 1979).

Except for this case, which needs to be confirmed by more analyses (those reported here are not very precise because of the non-gaussian distribution and the high value of the coefficient of variation for green plant regeneration), the androgenetic lines did not show a particular behaviour in diallel cross as regards general and specific reciprocal effects.

The analysis of mitochondrial DNA by restriction fragment electrophoresis confirmed the biometric analysis and the cytoplasmic stability of androgenetic lines. It is however necessary to state that mt DNA analysis by the restriction enzymes method only permits the discovery of fairly large alterations, which considerably change the molecular weight of a fragment. This method also enables the visualisation of point mutations taking place inside a restriction site. But, from this point of view, the coverage of the mitochondrial genome is not at all correct: if we consider an average of 50 restriction sites per enzyme, with an average length of 6 base pairs, about 300 base pairs are 'covered' per enzyme, i.e. less than $2000 \mathrm{bp}$ with the 6 endonucleases used, only about $0.3 \%$ of the total length of the mitochondrial genome of $T$. aestivum estimated at 588000 base pairs (DELORME, 1983).

The similarity of two restriction patterns, even with several enzymes, does not allow one to affirm that the totality of $\mathrm{mt}$ DNA sequences are identical: the possibility of point mutations occurring on mt DNA outside the restriction sites cannot be excluded. It is however unlikely that major modifications of $\mathrm{mt}$ DNA like insertion or loss of a transposable element occur frequently during in vitro anther culture of triticale.

On the other hand, perturbations in the frequency of recombination between specific sites during in vitro culture could lead to changes in the steady-state level of particular alternative forms of mt DNA molecules, which might then be reflected in a quantitative change in the stoichiometry of certain restriction fragments (BORCK \& WALBOT, 1982 ; Mc NAY et al., 1984). But we did not find such modifications in any electrophoretic diagram. The mt DNA of the doubled haploid lines of triticale is thus apparently stable. Chloroplast DNA of both green and albino androgenetic plants will be analysed in further studies.

No cytoplasmic factors have been found which can satisfactorily explain reduced vigour and low productivity of certain doubled haploid lines of triticale obtained from in vitro androgenesis. There is no evidence of a particular behaviour of these lines in a complete diallel cross as regards the reciprocal effects on quantitative characters. Restriction fragment analysis of mt DNA confirms this cytoplasmic stability. Although these results obtained from only 5 androgenetic lines cannot be generalized, cytoplasmic variations presumably resulting from in vitro anther culture do not seem to occur frequently in triticale.

It would therefore seem necessary to consider other hypotheses than that of cytoplasmic variation to explain the phenomena of loss of vigour and productivity sometimes observed in androgenetic doubled-haploid lines : chromosome rearrangements (Mc CoY et al., 1982), nuclear mutations, modifications of nuclear gene redundancy, mainly in highly repetitive sequences such as those coding for ribosomal RNA (DE PAEPE $e t$ al., 1982, DHILLON et al., 1983).

Reçu le 28 août 1984. Accepté le 30 mars 1985.

\section{REFERENCES}

Bernard S., 1977. Etude de quelques facteurs contribuant à la réussite de l'androgenèse par culture d'anthères in vitro chez le triticale hexaploïde. Ann. Amélior. Plantes, 27, 639-655.

Bernard S., 1980. In vitro androgenesis in hexaploid triticale. Determination of physical conditions increasing embryoid and green plant production. Z. Pflanzenzücht., 85, 308-321.

Bork K. S., Walbot V., 1982. Comparisons of the restriction endonuclease patterns of mitochondrial DNA from normal and male-sterile cytoplasms of Zea mays L. Genetics, 102, 109-128.

Brown J. S., Wernsman E. A., 1982. Nature of reduced productivity of anther derived dihaploid lines of flue-cured tobacco. Crop Sci., 22, 1-5.
Burk L. G., Matzinger D. F., 1976. Variation among anther derived doubled haploids from an inbred line of tobacco. J. Hered., 67, 381-384.

Charmet G., Bernard S., 1984. Diallel analysis of androgenetic plant production in hexaploid triticale ( $\times$ Triticosecale Wittmack). Theor. Appl. Genet., 69, 55-61.

Chourey P. S., Kemble R. J., 1982. Transposition event in tissue cultured cells of maize. 5th Congr. Plant Tissue Cell Culture. Tokyo, Japan, 425-426.

Deaton W. R., Legg P. D., Collins G. B., 1982. A comparison of burley tobacco doubled haploid lines with their source inbred cultivars, Theor. Appl. Genet., 62, 69-74. 
Delorme S., 1983. Etude de la structure de l'ADN mitochondrial de blé ; mise en évidence de points de recombinaison. Thèse $3^{\mathrm{e}}$ cycle, Univ. Paris-Sud, 112 p.

De Paepe R., Prat D., Huguet T., 1982. Heritable nuclear DNA changes in doubled haploid plants obtained by pollen culture of Nicotiana sylvestris. Plant Sci. Lett., 28, 11-28.

Dhillon S. S., Wernsman E. A., Midsche J. P., 1983. Evaluation of nuclear DNA content and heterochromatin changes in anther derived dihaploids of tobacco (Nicotiana tabacum) cv. Coker 139. Can. J. Genet. Cytol., 25, 169-173.

Dixon L. K., Leaver C. J., Brettell R. I. S., Gengenbach B. G., 1982. Mitochondrial sensitivity to Drechslera maydis T. toxin and the synthesis of a variant mitochondrial polypeptide in plants derived from maize tissue culture with Texas male sterile cytoplasm. Theor. Appl. Genet., 63, 75-80.

Falconet D., Lejeune B., Quetier F., Gray W., 1984. Evidence for homologous recombination between repeated sequences containing $18 \mathrm{~S}$ and S5 ribosomal RNA genes in wheat mitochondrial DNA. Embo J., 3, 297-302.

Gengenbach B. G., Connelly J. A., Pring D. R., Conde M. F. 1981. Mitochondrial DNA variation in maize plants regenerated during tissue culture selection. Theor. Appl. Genet., 59, 161-167.

Griffing B., 1956. Concept of general and specific combining ability in relation to diallel crossing systems. Aust. J. Biol. Sci., 9, 463-493.

Kemble R. J., Flavell R. B., Brettell R. I. S., 1982. Mitochondrial DNA analyses of fertile and sterile maize plants derived from tissue culture with the Texas male sterile cytoplasm. Theor. Appl. Genet. 62, 213-217.

Kouadio S. Y., 1979. Analyse génétique de la variabilité dans une descendance de lignée pure de riz (Oryza sativa) variété Cigalon, traitée par androgenèse in vitro. Thèse Doct. Ing. $\left(\mathrm{N}^{\circ} 405\right)$, Univ. Paris-Sud, $161 \mathrm{p}$.

Larkin P. J., Scowcroft W. R., 1981. Somaclonal variation, a novel source of variability from cell cultures for plant improvement. Theor. Appl. Genet., 60, 197-214.

Larkin P. J., Ryan S. A., Brettell R. I. S., Scowcroft W. R., 1984. Heritable somaclonal variation in wheat. Theor. Appl. Genet., 67, 443-455.

Levings C. S. III, Shah D. M., Hu W. W. L., Pring D. R., Timothy D. H., 1979. Molecular heterogeneity among mitochondrial DNA from different maize cytoplasm. ICN-UCLA Symposium: Extrachromosomal DNA, 63-73, New York Academic Press.

Lonsdale D. M., Hodge T. P., Fauron C. M., Flavell R. B., 1983. A predicted structure of the mitochondrial genome from the fertile cytoplasm of maize, 454-456, In ; Goldberg R. B. : « Plant Molecular Biology". ICN-UCLA Symposium on molecular and cellular biology, vol. 12 .
Mc Coy T. J., Phillips R. L., Rines H. W., 1982. Cytogenetic analysis of plants regenerated from oats (Avena sativa L.) tissue culture : high frequency of partial chromosome loss. Can. J. Genet. Cytol., 24, 37-50.

Mc Nay J. W., Chourey P. S., Pring D. R., 1984. Molecular analysis of genomic stability of mitochondrial DNA in tissue cultured cells of maize. Theor. Appl. Genet., 67, 433-437.

Matzinger D. F., Burk L. G., 1984. Cytoplasmic modification by anther culture in Nicotiana tabacum L. J. Hered., 75, 167-170.

Oinuma T., Yoshida T., 1974. Genetic variation among D. H. Lines of burley tobacco varieties. Jpn. J. Breed., 24, 211-216.

Oono K., 1975. Production of haploid plants of rice (Oryza sativa) by anther culture and their use for breeding. Bull. Nat. Inst. Agric. Sci., D, 26, 139-222.

Palmer J. D., Shields C. R., 1984. Tripartite structure of the Brassica campestris mitochondrial genome. Nature, 307, 437-440.

Picard E., De Buyser J., Henry Y., 1978. Technique de production d'haploïdes de blé par culture d'anthères in vitro. Le Sélectionneur français, 26, 25-37.

Quetier F., Vedel F., 1977. Heterogeneous population of mitochondrial DNA molecules in higher plants. Nature, 268, 365-368.

San Noeum L. H., Ahmadi N., 1982. Variability of doubled haploids from in vitro androgenesis and gynogenesis in Hordeum vulgare, L. 273-283. In Earle \& Demarly : "Variability in plants regenerated from tissue culture ». N. Y. Acad. Press, 392 p.

Schaeffer G. W., 1982. Recovery of heritable variability in anther derived doubled-haploid rice. Crop Sci., 22, 1160-1164.

Sibi M., 1976. La notion de programme génétique chez les végétaux supérieurs. II, aspect expérimental. Obtention de variants par culture de tissus in vitro sur Lactuca sativa L., apparition de vigueur chez les croisements. Ann. Amélior. Plantes, 26, 523-547.

Simpson G. M. 1968. Association between grain yield per plant and photosynthetic area above the flag-leaf node in wheat. Can. $J$. Plant Sci., 48, 253-260.

Sun C. S., Wu S. C., Wang C. C., Chu C. C., 1979. The deficiency of soluble proteins and plastid ribosomal DNA in the albino pollen plants of rice. Theor. Appl. Genet., 55, 193-197.

Sun Z. X., Zhao C. Z., Zheng K. L., Qi X. F., Fu Y. P., 1983 Somaclonal genetics of rice, Oryza sativa L. Theor. Appl. Genet., 67, 67-73.

Vedel F., Quetier F., 1978. Hydrolyse spécifique de l'ADN chloroplastique et de l'ADN mitochondrial des végétaux supérieurs par les enzymes de restriction. Physiol. vég., 16, 411-425.

Vedel F., Quetier F., Cauderon Y., Dosba F., Doussinault G., 1981. Studies on maternal inheritance in polyploid wheats with cytoplasmic DNA's as genetic markers. Theor. Appl. Genet., 59, 239-245. 